\title{
Efficiency and Market Power in Pakistani Dairy Processing Industry in Pakistan
}

\author{
Dr. Nadeem Bhatti \\ Head of Faculty, North American College \\ 730, Young Street, Suit No.207, Toronto, Ontario, M4Y, 2B7, Canada \\ E-mail: nadbhatti@yahoo.com \\ Shoukat Ali Raza \\ Assistant Professor, IER, University of the Punjab, Lahore, Pakistan \\ Dr. Muhammad Aamir Hashmi \\ Assistant Professor, IER, University of the Punjab, Lahore, Pakistan
}

Dr. Ashi Zeeshan

Assistant Professor, IER, University of the Punjab, Lahore, Pakistan

Faiz M. Shaikh

Assistant Professor, SZABAC-Dokri, Sindh, Pakistan

E-mail: faizanmy2000@hotmail.com

Received: March 16, 2011

doi:10.5539/ass.v7n10p24

\author{
Accepted: May 17, $2011 \quad$ Published: October 1, 2011 \\ URL: http://dx.doi.org/10.5539/ass.v7n10p24
}

\begin{abstract}
This paper uses firm level data to examine the market power versus efficiency hypothesis by taking into consideration both the long run behavior of profitability and the possible endogeneity has among profitability market there, and advertising variables. In a sample of 5 dairy processing industries in Pakistan in the period of 2005to 2010 (July), two stage least squares results show both a direct effect of firm characteristics and an indirect effect of industry characteristics on profitability which do not provide support for the efficiency hypothesis alone but they do not show that profitability is affected by both firm and industry level.
\end{abstract}

Keywords: Market, Dairy industry, Efficiency, Profitability

\section{Introduction}

A number of studies suggested that both market power and efficiency affect profitability. Schmalensee states that collusion is more likely to the above competitive levels, the higher seller concentration is also where efficiency differences are important, more efficient firms obtain larger market share and earn rents, and both concentration and industry profitability are thus high. (Martin 1988) test the oligopoly and efficiency explanations of market power. His results suggest that the efficiency and market power hypotheses should be regarded as complementary rather than alternative (334). However above studies assumed that market share effects can be attributed to efficiency, and no attempt was made to test whether market share is determined by industry characteristics associated with monopoly power. This is in important when endogeneity problem exists in the estimation of the relevant profitability equation. Thus it is necessary to specify a model consisting of profitability market share and advertising equations and then to test the existence of simultaneity basis by using a formal specification test. The competitiveness of the Pakistani market for agricultural commodities, including dairy products, has been at the forefront of much debate in recent times in the context of recent reforms to the 
increasing trade liberalization brought about as a result of and increasing globalization of the world economy (Newman and Matthews, 2004). Consequently, the objective of this research was to examine the relative competitiveness of Pakistan's specialist milk producer's. The chosen samples for comparison, between pack milk producers Engro-foods, Nestle, Haleeb, Dairy queen, Good Milk, with in the Pakistani markets. Furthermore, additional analysis was conducted on 'representative' farm types from the domestic Farm Comparisons, based on a number of major domestic milk producing countries, to determine the relative international competitiveness of 'representative' Pakistan's specialist milk producers.

\section{Domestic Competition among tetra milk producers}

In addition to the comparison of costs within Pakistan using data from the domestic markets and cost competitiveness was examined using data from the different markets. The cost calculations within the Pakistani markets are based on individual representative farms, rather than on the results from stratified random samples of the population as is the case with in Pakistan data. Data provides a source of data which can be used to examine the relative domestic competitiveness of 'representative' Pakistan's milk producers. Data is assembled and analyzed using a common methodological framework. Like the methods outlined above, data also presents costs as total 'cash' costs, which consists of expenses from the profit and loss account (cash costs, depreciation, etc.) and total 'economic' costs with opportunity costs calculated for farm-owned factors of production (family labor, own land, own capital).

\section{Data Collection Methodology}

Data were collected from firm level data for the period 2005-210(July) to estimate long run values of all variables to test efficiency and/or market power hypotheses by a simultaneous system consisting of these equations (profitability, market share, advertising)corresponding to SCP variables. We treat as endogenous three firm level variables profitability, market share and advertising in five dairy processing industries, i.e. Engro-food, Haleeb, Nestle, Good Milk, and Noor Milk. Long term and industry level variables are used to show whether firm and industry characteristics are more important determinants of the performance. Data from all farms are collected from specialist dairy farms actually in operation or from specialist farms modeled directly from regional dairy farming operations. It is fair to say that the methodological approaches towards improving the validity of comparisons, across the world wide countries participating, are still developing as the domestic markets is of recent vintage. Therefore, it is probably more useful for those examining the results comparisons to view them as indicative of rather than as an absolute statement on the competitive position of a Pakistan's dairy industry. Keeping this in mind, we present comparative results for some important measures of financial and economic performance for the years 2007-08.

\section{Model Specification}

We have developed three equation model in which profit, market share, and advertising are jointly determined. The model takes the general form provided below:

$$
\begin{array}{ll}
\mathrm{PR}= & f 1(\mathrm{MS}, \mathrm{ADV}, \mathrm{XI}) \\
\mathrm{MS}= & f 2(\mathrm{ADV}, \mathrm{PR}, \mathrm{X} 2) \\
\mathrm{ADV}= & f 3(\mathrm{PR}, \mathrm{MS}, \mathrm{X} 3)
\end{array}
$$

Where PR is firm profitability, MS is market share, ADV is firms advertising, $\mathrm{X} 1, \mathrm{X} 2, \mathrm{X} 3$ are vectors of exogenous variables.

\section{Profitability Equation}

Following Mueller (p.111) firms are allowed to differ with respect to both their product characteristics and their costs. The $i$ th firms demand schedule in a given industry is then

$$
\mathrm{P}^{\mathrm{i}=} \alpha_{\mathrm{i}}-b \mathrm{x}_{\mathrm{i}}-\sigma \mathrm{b} \sum \mathrm{x}_{\mathrm{i}}
$$

Where $\mathrm{p}$ is the firm I's price $\mathrm{xj}$ is other firm output, and firm I's total cost function is:

$$
\mathrm{TCi}=\quad \text { cixi }
$$

The parameter is interpreted as an index of the perceived quality, of the firms ith firms product. The $\sigma$ parameter is the degree of substitutability of the one of firm's product for another $0<\sigma<1$. Then with the little manipulation equation (4) yield expression of firm $i$ 's profitability in the presence of product differentiation:

$$
\mathrm{IIi} / \mathrm{Si}=1 / \eta\left\{\left(\begin{array}{lllll}
\mathrm{mi} & / & \sigma
\end{array}\right)-\theta \mathrm{mi}+\theta\right.
$$


Where the mi is firm $i$ 's market share, $\eta$ is the industry demand elasticity and $\theta$ is the degree of cooperation, which according to Muller (p.77) is the function of long run industry concentration ratio (CR4L), the above equation implies that firms profitability is the function of long run market share (MSL), concentration (CR4L), the degree of substitutability among products, and of all the factors that affect elasticity of demand one variable is associated with product differentiation is long term advertising (ADVL) which is both cause and effect of product differentiation. Based on equation (6) the model which is going to be estimated is the following:

$$
\mathrm{PRL}=\mathrm{a} 0 \quad+\mathrm{a} 1 \quad \mathrm{MSL}+\mathrm{a} 2 \mathrm{KSL}+\mathrm{a} 5 \quad \mathrm{GRIL}+\mathrm{a} 6 \mathrm{CRMS}
$$

Where PRL is the long-run profitability of the firm, that is the profit to asset ratio expressed as a percent, MSL is the long run firm market share, ADVL is the long run advertising variable. CR4L is the long run four firm concentration-ratio, GRIL is the long run growth of the industry demand, and CRMS is the interaction of CR4 and MS.

It has been argued that market share rather than four firm concentration ratio is the main determinant of market performance and competition (Geroski). This is why almost all the studies that have been carried out with firm level data associate with market share profit rate. A part from market share $\left(a_{1}>0\right)$. The four firm concentration ratio is also included to test whether market share or market concentration is the main direct determinant of performance $\left(a_{3}>0\right)$. Since advertising intensity affect the electricity of demand and determines market structure, higher advertising intensity is expected to result in higher profitability $\left(a_{4}>0\right)$. Market growth is included to capture changing demand conditions. An increase in market growth is expected to affect profitability of the firm positively $\left(a_{5}>0\right)$.

\section{Market share equation}

Following other studies (Martin 1993) model for market share is the following.

$$
\mathrm{MSL}=\mathrm{b}_{0}+\mathrm{b}_{1} \mathrm{ADVL}+\mathrm{b}_{2} \text { PRL }+\mathrm{b}_{3} \mathrm{KSL}+\mathrm{b}_{4} \mathrm{GRFL}+\mathrm{b}_{5} \text { GRIL }+\mathrm{b}_{6} \text { MESL }
$$

Where MSL is the firm's long run market share, ADVL is the firm's long run advertising intensity; PRL is the long run profitability. KSL is the long run fixed-assets-sales ratio, GRFL and GRIL are the long run growth of the firm's and industry demand respectively, and MES is the long run minimum effect.

Economies of scale are included in the equation to test whether the firm market share is determined by the industry variables associate with barriers to entry and monopoly power. MES serves as a technical barrier to entry created by economies of scale, and should be critical to market share models because it is a proxy for the exogenous sunk costs a firm must commit of enter an industry (Sutton, p.98) It is expected that the greater the magnitude of scale of economies, reflected in MES, the higher the market share $\left(a_{6}>0\right)$.

\section{Advertising Equation}

The dorfman-Steiner (1954) condition for optimal advertising intensity is given as follows:

$$
\mathrm{PA} / \mathrm{Q} \mathrm{P}=[(\mathrm{P}-\mathrm{C}] \mathrm{eQA}
$$

Where $\mathrm{A}$ is advertising expenditures, $\mathrm{PA}$ is the cost of current advertising. $\mathrm{P}$ is the product price. $\mathrm{Q}$ is the quantity and $\mathrm{QAA}$ is the elasticity of demand with respect to advertising, while

$(\mathrm{P}-\mathrm{C}) / \mathrm{P}$ is price cost margin. In most of the studies $\mathrm{P}_{\mathrm{P}}^{\mathrm{A}} / Q P$ is measured as total advertising expenditures over sales, while many empirical studies argue that the ratio of profit over sales can be used as a proxy for price cost margins (Uri, Molyneux and Forbes, Vlachvei and Oustapassidis). By multiplying both sides by sales over capital ratio, we obtain

$$
\mathrm{A} / \mathrm{K}=(\mathrm{PR} / \mathrm{K}) \text { eQA }
$$

The above equation, suggests that advertising over asset ratio is the function of profit over asset ratio and elasticity of demand with respect to advertising. Therefore, following other similar IO studies (Uri. Pagoulatos and Sorensen, Oustapassidis and Vlachvei), we estimate equation as:

$$
\mathrm{ADVL}=\mathrm{Co}+\mathrm{C} 1 \mathrm{MSL}+\mathrm{C}_{2} \mathrm{PRL}+\mathrm{C}_{3} \mathrm{CR} 4 \mathrm{~L}+\mathrm{C}_{4} \mathrm{CRL}^{2}+\mathrm{C}_{5}
$$

Where ADVL, is the firm's long-run advertising measured as advertising expenditures over assets, MSL is the long-run market share, $\mathrm{PRL}$ is the long-run firms profitability $\mathrm{CR} 4 \mathrm{~L}$ is the long run concentration ratio, $\mathrm{CR} 4 \mathrm{~L}^{2}$ is the square value of concentration ratio, and GRIL is the long-run industry growth.

\section{Simulation and Model Estimation}

A formal way to test whether correlation between right hand side endogenous variables and the error term are so strong that instrumental variables estimation techniques need to be used is provided by the Hausman-Wu test 
(Maddala). The results of Hausman Test (table-1) show that an endogeneity problem does exist in both the advertising and market share equations. Two stage least square (2SLS) estimates appear in table-1. The profit equation is $\mathrm{f}$ particular interest. It is evident that the coefficient of market share is positive and statistically significant, indicating that large market shares lead to increase an profit margin of the firms. Furthermore the results show that high concentration does not lead to an increase in profitability. Concentration is not found to affect profitability significantly If these results will taken alone they would support in efficiency hypothesis that large firms makes more profits through their efficient operation while the effect of concentration does not provide support for the co-coordinated behavior or collusive market power, hypothesis. The coefficient of advertising is positive and significant, showing that product differentiation plays an important role in determining monopoly power. The variables of capital intensity and growth are not found to be significant in the profitability equation.

\section{Insert Table 1 Here}

However the results from the other two equations are also very interesting. They show that market share is affected positively by the firm advertising intensity and by the existence of economies of scale which is an industry characteristic. Similarly firm advertising intensity is affected by firm profitability. These results show that profitability is determined, directly or indirectly, by both firm and industry characteristics, which provide support neither for the efficiency nor for the market power hypotheses taken alone. The results which are consistent with other studies (e.g Muller) suggest that both industry and firm characteristics determine profit.

\section{Comparison of partial productivity measures on selected dairy farms}

In Figures $1 \mathrm{a}$ and $1 \mathrm{~b}$ below the partial productivity indicators identified above are outlined for the six tetra milk producers compared in this analysis. The results are presented for all specialist dairy farms in the sample and weighted to estimates of population means. The results presented here for each of the firm the average for the years January 2007-09January.

\section{Insert Figure 1a Here}

Figure 1a shows that average milk yields per dairy cow were much lower in the case of Engro-food relative to the other countries in the analysis. Average yields in the Haleeb and Nestle were substantially higher than the other milk producers. Comparisons of milk solids per cow showed an even greater disparity between Ireland and the other countries. In particular, milk solids per cow in the farms of Dairy Queen and Haleeb were 30 per cent and 32 per cent higher respectively. The levels of land productivity in the Of Engro-foods were also relatively high, at 34 per cent and 30 per cent higher than in Nestle.

\section{Insert Figure 1b Here}

The combination of the generally lower stocking densities and lower milk yields for Engro-foods is aggregated in the next two measures of productivity. Milk production and milk solids per hectare were lower in Baluchistan Province than for all other parts of the country. The Dairy Queen and Good Milk again exhibited rates well in excess of the other producers examined, with milk production per hectare 70 per cent higher in Islamabad and 10 per cent higher in Baluchistan the big cities and compared to small. Differences in milk solids per hectare were even more pronounced in other areas relative with levels in both more than double those recorded. The final partial productivity measure - milk production per labour unit was again highest in the Sindh and Punjab, with levels in the NWFP also relatively high.

\section{Conclusions}

This paper uses the long run values of SCP variables from six dairy processing industries in Pakistan, to examine the market power versus efficiency hypothesis. Long-run values were estimated from all variables from 2005-10 to overcome with the problem of product differentiation. A three equation system of profitability, advertising and market share was specified and appropriate test was used to examine the existence of endogeneity bias. The efficiency hypotheses was tested here by using long-run values of the variables and considering the endogeneity bias which has not been taken an account by previous studies examining this hypothesis. The evidence presented here clearly supports the even using long-run values of SCP determinants; both efficiency and market power determine firm profitability. 2SLS results show a significant and positive relationship between profitability and market share, which s enjoying by Engro-food in dairy processing industry followed by Nestle. Thus the results support that both firm and industry characteristics are important in explaining profitability differences across firms. 


\section{References}

Bain J.S. (1956). Barriers to new competition. Cambridge MA: Harvard University press.

Clarke, R.S. Davies, and M, Watterson. (1984). The profitability concentration Relation: market power of efficiency. J.Indust. Economics, 32, December, 435-49. http://dx.doi.org/10.2307/2098228

Collins, N.R., and L.E. Preston. (1969). Price-cost Margins and Industry Structure. rev. Econo. and Statistics, 51, August, 226-42.

Connor, J., R. Rogers, and V.Bhagavan. (1996). Concentration. Change and countervailing power, Economics of innovation: The case of food industry. G.Galizzi and L.Venturini, eds, Heidelberg: Physica-Verlag.

Demsetz, H. (1973). Industry structure market Rivalry and public policy. J. Law Economic, 16, April, 1-9. http://dx.doi.org/10.1086/466752

Gale, B., and B. Branch. (1982). Concentration versus market share: which determines performance and why does it matter? Antitrust bull, 27, 83-105.

Geroski, P. (1988). Competition policy structure performance Paradigm, Economics of Industrial organization. Davis et al., eds. London: Longman.

Maddala, S. (1992). Introduction to Econometrics. New York: Macmillan.

Martin, S. (1988). Market power and efficiency, rev. Econo. and Statistics, 70, May, 331-35.

Muller, D. (1986). Profit in the long-run. Cambridge UK: Cambridge University Press. http://dx.doi.org/10.1017/CBO9780511664731

Oustapassidis, K., and A. Vlachvei. (1999). Profitability and product differentiation in Greek food industries. Applied Economics, 31, September, 1293-98. http://dx.doi.org/10.1080/000368499323508

Sutton, J. (1991). Sunk costs and market structure. Cambridge MA:MIT Press.

Zellner, J.A. (1989). A simultaneous Analysis of food industry Conduct American. J. Agri. Economics, 71, February, 105-15. http://dx.doi.org/10.2307/1241779

Table 1. SLS Regression Result for Dairy Food Manufacturing Firms 2005-2010

\begin{tabular}{|c|c|c|c|}
\hline Variables & PRL & MS L & ADVL \\
\hline MSL & $\begin{array}{l}-0.54 \\
(-3.48) \\
0.73\end{array}$ & $\begin{array}{l}-0.05 \\
(0.78)\end{array}$ & $\begin{array}{l}0.02 \\
(3.09) \\
-0.002 \\
(-0.10)\end{array}$ \\
\hline ADVL & $\begin{array}{l}(2.51) \\
5.37 \\
(2.93) \\
0.31 \\
1.04\end{array}$ & $\begin{array}{l}5.98 \\
(2.14)^{* *}\end{array}$ & $\begin{array}{l}-0.01 \\
(-1.24) \\
*\end{array}$ \\
\hline PRL & & & $\begin{array}{l}-0.01 \\
(-1.24) \\
0.00003 \\
(1.24) \\
0.06 \\
(3.66)^{*}\end{array}$ \\
\hline KSL & $\begin{array}{l}-0.005 \\
(-1.68)\end{array}$ & $\begin{array}{l}0.14 \\
(1.09) \\
0.35 \\
(4.15)\end{array}$ & \\
\hline GRIL & $\begin{array}{l}-0.04 \\
(-1.68)\end{array}$ & $\begin{array}{l}0.14 \\
(1.09) \\
0.35 \\
(4.15)^{*}\end{array}$ & \\
\hline MESL & & $\begin{array}{l}(1.09) \\
(0.35) \\
(4.15\end{array}$ & $\begin{array}{l}0.002 \\
(1.25)\end{array}$ \\
\hline CRMS & & $\begin{array}{l}0.39 \\
(-1.04) \\
0.32\end{array}$ & \\
\hline R2 & 0.32 & 0.23 & 0.26 \\
\hline Hausman test F-Value & 0.60 & 18.62 & 7.90 \\
\hline Number of observation & 266 & 266 & 266 \\
\hline
\end{tabular}

Note: * and $* *$ denote statistical significant at $1 \%$ and $5 \%$ level of significance respectively. 


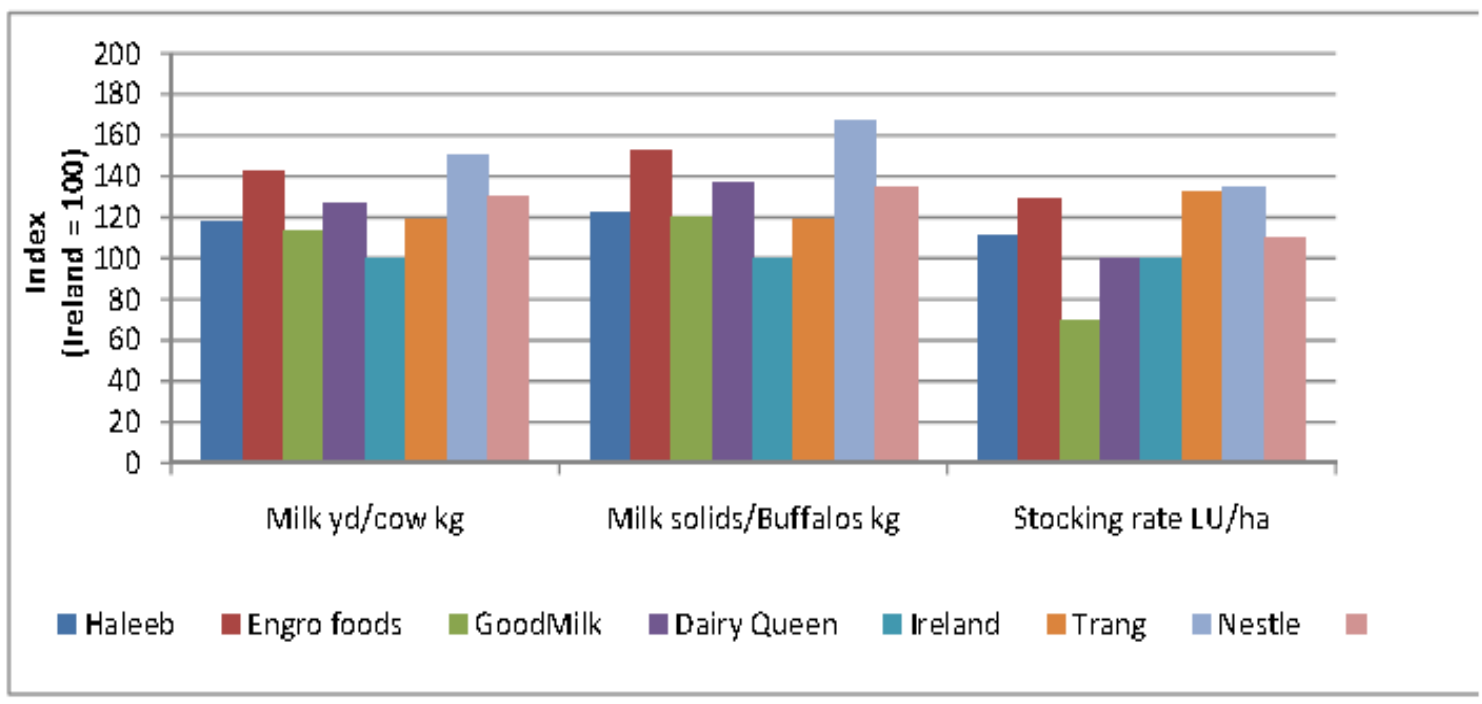

Figure 1a. Partial Productivity Measures for the different brands in Dairy industry in Pak

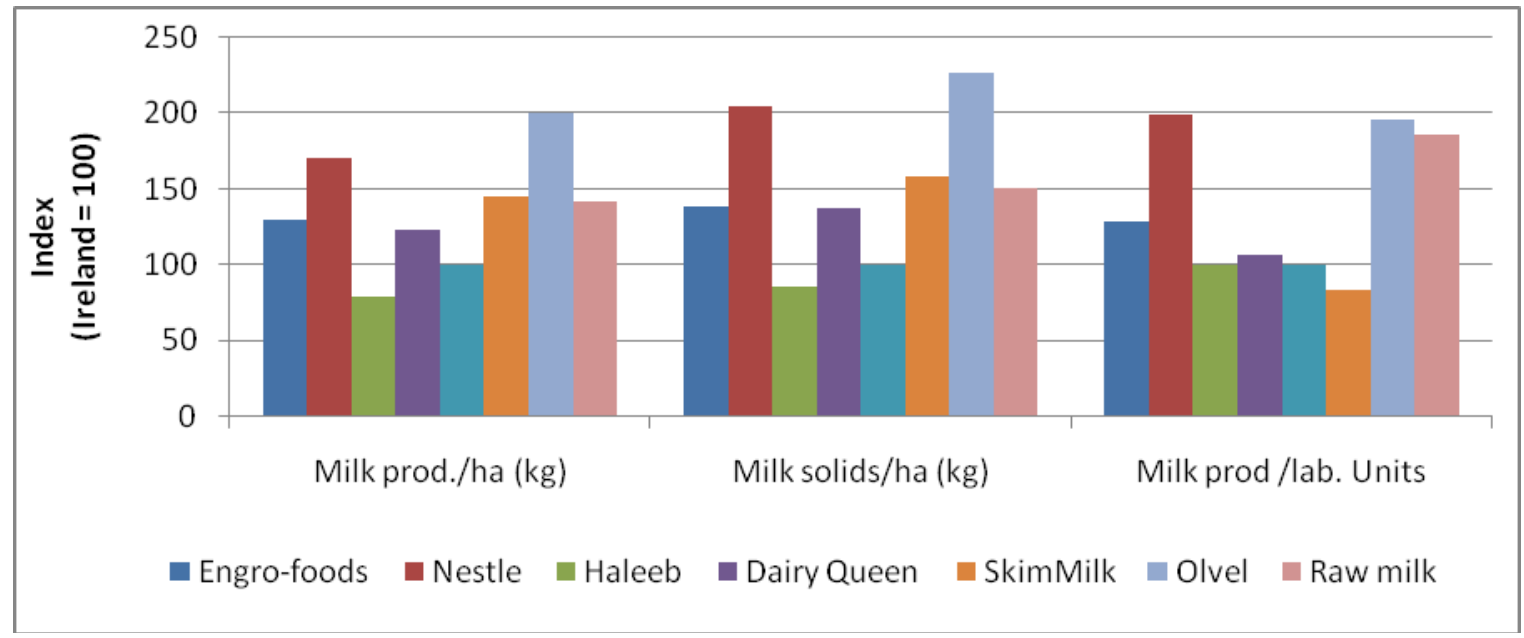

Figure 1b. Partial Productivity Measures for selected Tetra Milk Product Brands 